\title{
Simple and Rapid Cell Growth Estimation Method for Thiobacillus ferrooxidans and the Growth Rate in the Presence of Polyoxyethylenes
}

by Naoki HIROYOSHI ${ }^{1}$, Mayumi ITO ${ }^{1}$, Masami TSUNEKAWA ${ }^{1}$ and Tsuyoshi HIRAJIMA ${ }^{1}$

1. Faculty of Engineering, Hokkaido University, Kita-ku, Sapporo 060

\begin{abstract}
Conventional turbidity method can not be used to estimate the cell growth of Thiobacillus ferrooxidans, because ferric precipitates (ferric hydroxide and jarosites) are formed in the medium due to bacterial oxidation of ferrous ions. In this paper, a modified turbidity method is proposed and demonstrated. The microorganisms were grown in $9 \mathrm{~K}$ medium and the culture medium was sampled periodically. The sample medium was mixed with equal volumes of $6 \mathrm{~N} \mathrm{HCl}$ to dissolve ferric precipitates. The precipitates dissolved completely after 30 minutes. The turbidity of the mixed solution was measured by nephelometer after the dissolution. During the culture, the turbidity increased exponentially, then reached a constant value, corresponding to exponential and stationary phases on the growth curve. The specific growth rate obtained from the turbidity curve agreed with the rate from the direct cell counting. The proposed method is more simple and rapid than the direct cell counting and protein assay that are usually used to estimate the cell growth of Thiobacillus ferrooxidans.

Using the modified turbidity method, the growth rates of Thiobacillus ferrooxidans in $9 \mathrm{~K}$ medium containing 0 to $1,000 \mathrm{~g} / \mathrm{m}^{3}$ of Tween 20 , Brij35, or polyethyleneglycol were investigated. With addition of $1,000 \mathrm{~g} / \mathrm{m}^{3}$, all three polyoxyethylenes markedly suppressed the bacterial ferrous oxidation and cell growth.
\end{abstract}

KEY WORDS : Thiobacillus ferrooxidans, Growth Rate, Turbidity, Polyoxyethylenes

\section{1. 緒}

代表的な鉄酸化細菌であるThiobacillus ferrooxidans の種々 の条件下における増殖挙動を把握することは, バクテリアリーチ ング, 鉱廃水処理等での同菌の積極的な活用を計る上で重要であ る。T. ferrooxidans の菌体量測定には, 従来, 直接計数法や夕 ンパク質量測定法が用いられている。これらの方法は測定に手間 と時間を要するため, 調べたい因子の数が多い場合には, より簡 便で迅速な方法が望まれる。大腸菌などの場合には, 培養液中の 菌体によって生じる濁りを測定する濁度法が簡便法として広く用 いられている。しかし，鉄（II）イオンを基質とした $T$. ferrooxidans の培養過程ではジャロサイト, 水酸化鉄 (III)等の鉄 沈殿が生成してくるため, 濁度法を用いることができなかった。

\footnotetext{
* 1995 年 11 月 16 日受付 1996 年 1 月 24 日受理 1995 年度資源・素材学 会春季大会にて一部発表

1. 正会員 北海道大学助手 工学部資源開発工学科

2. 学生会員 北海道大学大学院学生 資源開発工学専攻

3. 正会員 工博 北海道大学教授 工学部資源開発工学科

4. 正会員 工博 北海道大学助教授 工学部資源開発工学科

〔著者連絡先〕 FAX 011-716-6175 (北大·資源)

キーワード：チオバシラス フェロオキシダンス，増殖速度，濁度法，ポリオ キシエチレン化合物
}

そこで本研究では, 培養液中の鉄沈殿を酸によって溶解した後に 濁度を測定する方法 (酸添加濁度法) を考案し, 従来法 (直接計 数法, タンパク質量測定法) と比較検討した。また, バクテリア リーチングの浸出促進剤として期待されている数種のポリオキシ エチレン化合物（Duncan ら，1964；広吉ら，1994，1995； Sandval ら, 1991) 存在下での T. ferrooxidans の増殖挙動につ いて酸添加濁度法を用いて調べ，本法の有用性を確かめた。

\section{2. 供試菌株，培地および試薬}

本研究に用いた微生物は, 豊羽鉱山酸性坑内水から分離培養し たもの（広吉ら，1992）であり，T. ferrooxidans と考えられる。 同菌の培養には, 9K 培地（Silverman ら，1967）あるいは, 9K 培地に所定濃度のポリオキシエチレン化合物を添加したものを使 用した。

ポリオキシエチレン化合物には, 非イオン性界面活性剤として ポリオキシエチレンソルビタンモノラウレート（和光純薬, 以下 では Tween 20 と記す）とポリオキシエチレンラウリルエーテル (和光純薬, 以下では Brij35 と記す) を, また, ポリエチレング リコールとしてPEG200, PEG2000, PEG20000 (和光純薬, 数 字は平均分子量を表す）を用いた。他に用いた試薬は，いずれも 市販の試薬特級である。 


\section{3. 実 験 方 法}

\section{$3 \cdot 1$ 培養方法および菌体懸濁液の調製方法}

T. ferrooxidans は，既報に述べた方法（広吉ら，1992）で $9 \mathrm{~K}$ 培地を用いて前培養し, 集菌・洗浄の後, 所定の組成の培地にお よそ $1 \times 10^{7} \mathrm{cells} / \mathrm{cm}^{3}$ となるように懸濁して実験に供した。500 $\mathrm{cm}^{3}$ 三角フラスコにこの植菌した培地 $165 \mathrm{~cm}^{3}$ を加え, フラス コ開口部にシリコ栓をした後, 恒温回転振盪機を用いて $30{ }^{\circ} \mathrm{C}$, $120 \mathrm{rpm}$ の条件で振盪培養した。所定時間が経過するごとに培養 液数 $\mathrm{cm}^{3}$ を採取し， 3 ・ 2 に述べる方法で濁度，鉄（II )イオン 濃度を測定した。一部の実験では, 数本のフラスコで培養を行い, 所定時間が経過するごとにフラスコ 1 本を振盪機から取り出して 培養液を全量採取し, 濁度, 鉄( II )イオン濃度の他にタンパク質 量, 菌体数についても測定した。

また，比較のため，次の方法で調製した菌体懸濁液についても， 3 ・2 の方法に従い濁度を測定した。上述のように $9 \mathrm{~K}$ 培地で前 培養後, 集菌, 洗浄した T. ferrooxidans $0.01 \mathrm{~mol} / \mathrm{dm}^{3}$ 硫酸 に懸濁して菌体懸濁液原液とした。菌体懸濁液原液をさらに 0.01 $\mathrm{mol} / \mathrm{dm}^{3}$ 硫酸で希釈して, 種々の濃度の菌体を含む菌体懸濁液 を調製した。なお，この際，菌体懸濁液原液を $1 / n$ の濃度に薄 めたとき，この菌体懸濁液の希䣋率を $n$ と表記する。

$3 \cdot 2$ 分析法

$3 \cdot 2 \cdot 1$ 濁度 採取した培養液または菌体懸濁液 $3 \mathrm{~cm}^{3}$ と $6 \mathrm{~N}$ 塩酸 $3 \mathrm{~cm}^{3}$ を試験管に採り,すばやく混和した後, 石英ガ ラスセルに移して, この混合液の濁度（散乱光強度の透過光強度 に対する比率）をボイック積分球式濁度計（日本精密工学, SEP-PT-201）で測定した。本濁度計では，JIS K0101に従って 調製した $1 \mathrm{~g} / \mathrm{m}^{3}$ のカオリン懸濁液の濁りが $1 \mathrm{ppm}$ として表示 される。以下では便宜上，この基準による読みとり值を濁度

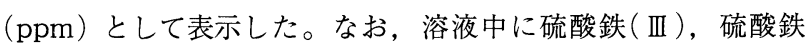
（II），ポリオキシエチレン化合物が存在しても測定に影響しない ことは, 予備実験により確認した。

$3 \cdot 2 \cdot 2$ タンパク質量 前記 $(3 \cdot 1)$ のフラスコ中の 培養液 $100 \mathrm{~cm}^{3}$ を遠沈管に入れ，遠心分離 $(16,000 \times g, 10$ min）により菌体を沈降させた後, 上澄み液を捨てた。ついで遠 沈管に $1 \mathrm{~N}$ 水酸化ナトリウム $5 \mathrm{~cm}^{3}$ を加え，攪拌して菌体を可溶 化した後, イオン交換水 $5 \mathrm{~cm}^{3}$ を添加した。その後, 鉄沈殿を 遠心分離 $(5,333 \times g, 5 \mathrm{~min})$ により沈降除去し, 上澄みに含ま れるタンパク質量を Lowry 法（日本生物工学会，1992）により 測定した。

$3 \cdot 2 \cdot 3$ 菌体数 少量の培養液をバクテリア計数盤に採 り，600 倍の位相差顕微鏡下で菌体数を直接計数した。

$3 \cdot 2 \cdot 4$ 鉄 (II )イオン濃度 鉄 (II)イオン濃度は, 1-10 オルトフェナントロリン法により測定した。ポリオキシエチレン 化合物が本測定に影響しないことは, 予備実験により確認した。

\section{$3 \cdot 3$ 酸素移動容量係数}

内容量約 $20 \mathrm{~cm}^{3}$ のガラス容器に, $1,000 \mathrm{~g} / \mathrm{m}^{3}$ の濃度のポリオ キシエチレン化合物を含む無菌培地 $7 \mathrm{~cm}^{3}$ とマグネチックスター ラの攪拌子を入れた。ついで, この容器を密閉するため, ガス挿 入管, ガス排出管および溶存酸素電極を挿入したゴム栓を容器開 口部に, 取り付けた。この際, 電極は培地に浸漬し, ガス挿入管 および排気管の先端は容器内培地上の気相部分に位置するように した。ガス挿入管を培地に浸漬しなかったのは，界面活性剤を含 む培地にガスを導入した際に生ずる気泡により気液界面積が増大 するのを防ぐためである。なお，溶存酸素電極は， $30{ }^{\circ} \mathrm{C}$ の空気 飽和イオン交換水に浸漬したときの指示值が $100 \%$ となるよう
にあらかじめ調整してある。容器を $30{ }^{\circ} \mathrm{C} に$ 保った恒温槽中に置 き,スターラにより培地を攪拌しながら，ガス挿入管より空気を 送気し, 電極の指示值が一定值 $\left(C^{\prime}[\%]\right)$ になるのを待った。 このときの指示值は飽和酸素濃度に対応するものである。次いで, 送気ガスを窒素に替え, 電極の指示值が $8 \%$ 以下になるのを待 ち, 再び送気ガスを空気に替えて酸素濃度の経時変化を測定した。 この測定結果から酸素移動容量係数 $A$ を, 次式より求めた。

$$
\ln \left(\frac{C^{\prime}-C}{C^{\prime}-C_{0}}\right)=A \cdot t
$$

$t$ は送気ガスを窒素から空気に切り替えてからの経過時間 $[\mathrm{h}]$, $C$ は時間 $t$ での電極の指示值 $[\%], C_{0}$ は, 送気を窒素から空気 に切り替えたときの電極の指示値 [\%] である。

\section{4. 結果および考察}

\section{4 ・ 1 酸添加濁度法による T. ferrooxidans 增殖量の測定}

鉄（II）イオンを基質とした T. ferrooxidans の培養過程では, T. ferrooxidans の作用により鉄 (II)イオンが酸化され, 鉄 (III) イオンが生成してくる(式 $(2))$ 。この鉄 (III) イオンが加水分解さ れることにより水酸化鉄, ジャロサイトなどの沈殿が形成される (式(3), 式(4))。

$$
\begin{aligned}
& \mathrm{Fe}^{2+}+\mathrm{H}^{+}+1 / 4 \mathrm{O}_{2} \rightarrow \mathrm{Fe}^{3+}+1 / 2 \mathrm{H}_{2} \mathrm{O} \\
& \mathrm{Fe}^{3+}+3 \mathrm{H}_{2} \mathrm{O} \rightarrow \mathrm{Fe}(\mathrm{OH})_{3(\mathrm{~s})}+3 \mathrm{H}^{+} \\
& 3 \mathrm{Fe}^{3+}+\mathrm{A}^{+}+6 \mathrm{H}_{2} \mathrm{O}+2 \mathrm{H}_{2} \mathrm{SO}_{4} \rightarrow \\
& \quad \mathrm{AFe}_{3}\left(\mathrm{SO}_{4}\right)_{2}(\mathrm{OH})_{6(\mathrm{~s})}+10 \mathrm{H}^{+}
\end{aligned}
$$

式(4)中の $\mathrm{A}^{+}$は, 培地中に含まれる $\mathrm{NH}_{4}^{+}, \mathrm{Na}^{+}, \mathrm{K}^{+}$など の一価陽イオンである。これらの沈殿を溶解するために用いる酸 の種類および濃度について予備的に検討したところ，6N 塩酸が 有効であった ${ }^{a)}$ 。T. ferrooxidans を $9 \mathrm{~K}$ 培地で培養し, 所定時間 ごとに採取した培養液 $3 \mathrm{~cm}^{3}$ に $6 \mathrm{~N}$ 塩酸 $3 \mathrm{~cm}^{3}$ を添加した場合の 濁度の経時変化を Fig. 1 に示す。図中の $\theta$ は； T. ferrooxidans の培養時間である。培養時間 52,75 および $100 \mathrm{~h}$ の場合, 培養 液中には多量の鉄沈殿が認められ，この沈殿が酸により溶解され

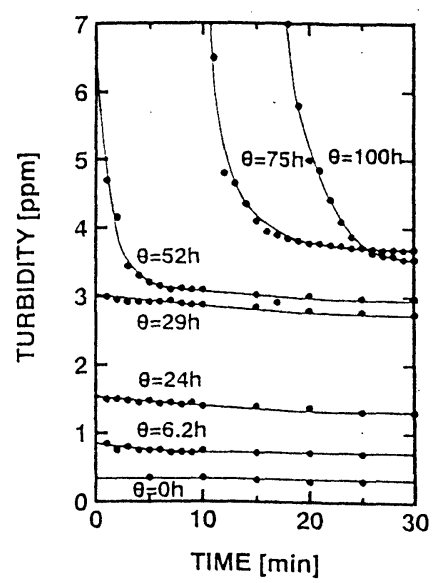

Fig. 1 Turbidity of the culture solutions mixed with $6 \mathrm{~N}$ $\mathrm{HCl}$ as a function of time. $\theta:$ incubation time

a） 9K 培地で T. ferrooxidansを培盖し, 静止期に達した後, 多量の鉄沈殿を 含む培養液を採取し, この培養液 $5 \mathrm{~cm}^{3}$ と酸 $5 \mathrm{~cm}^{3}$ を試験管中で混和, 攪 找した後, 視察した。(1:5) 硫酸, 60 \% 過塩素酸, $3 \mathrm{~N}$ 塩酸を添加した場 合, 30 分を経過しても鉄沈殿が認められた。 $8 \mathrm{~mol} / \mathrm{dm}^{3}$ りん酸を添加した 場合, 沈殿は急速に溶解したが, 溶液の粘性が高く，攪拌時に生じた気泡 が混合液中に長時間残留した。6 $\mathrm{N}$ 塩酸を添加した場合, 鉄沈殿は迅速に溶 解し, 気泡も残留しなかった。そこで, 以降の実験では $6 \mathrm{~N}$ 塩酸を用いるこ ととした。 


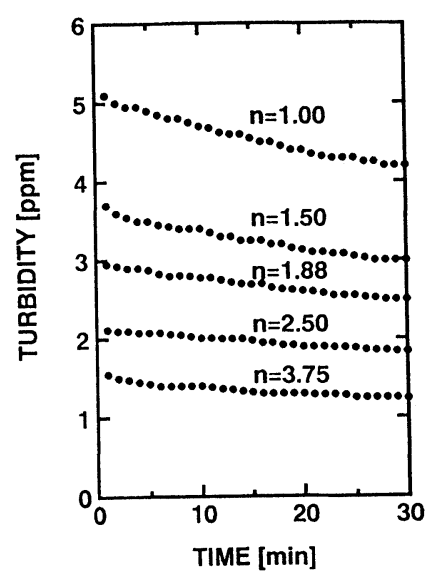

Fig. 2 Turbidity of the cell suspensions mixed with $6 \mathrm{~N} \mathrm{HCl}$ as a function of time. $n$ : dilution

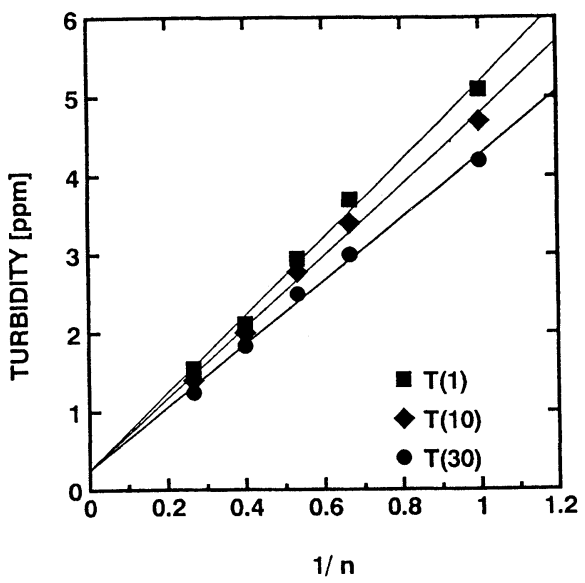

Fig. 3 Relationship between $1 / n$ and turbidity of the cell suspensions mixed with $6 \mathrm{~N} \mathrm{HCl}$.

$T(1), T(10)$ and $T(30)$ indicate the turbidity measured at 1,10 and 30 minutes after the mixing, respectively.

$n$ : dilution

るため, 酸添加直後に濁度が急激に減少し，それぞれ約 7,17 お よび $25 \mathrm{~min}$ 以上経過すると濁度の減少が緩やかになった。また, 培養時間の長いものほど, 濁度の值は高くなる傾向を示した。培 養時間 0〜29h の場合, 培養液中に鉄沈殿は認められなかったが, 濁度は時間の経過に伴い緩やかに低下した。これは，菌体自体に よって生じる濁度が $6 \mathrm{~N}$ 塩酸の添加により低下することに起因す る。このことは次のような実験で確かめることができる。すなわ ち，良く洗浄した T. ferrooxidans $0.01 \mathrm{~mol} / \mathrm{dm}^{3}$ の硫酸中に 種々の希釈率で懸濁し，これに $6 \mathrm{~N}$ 塩酸を添加して濁度の経時変 化を調べた。この実験結果を Fig. 2 に示す。いずれの希釈率の 場合も, 濁度は時間の経過に従い低下した。なお, 塩酸を添加し ない場合には濁度の低下は認められなかった。Fig. 3 に, 希釈 率の逆数と酸添加後 $1,10,30 \mathrm{~min}$ 経過した時点での濁度, す なわち $T(1), T(10), T(30)$ との関係を示す。希棌率 $n$ の逆数 と同一時間における濁度との間には直線関係が認められた。希釈 率 $n$ の逆数は菌体量と比例するから, Fig. 3 の結果は濁度と菌体 量が比例することを示すものであるが, その比例係数は酸添加後 の経過時間とともに変化する。

以上に示したように，培養液に $6 \mathrm{~N}$ 塩酸を添加した場合，1)沈 殿の溶解にある程度の時間が必要であり，2)菌体自体によって生

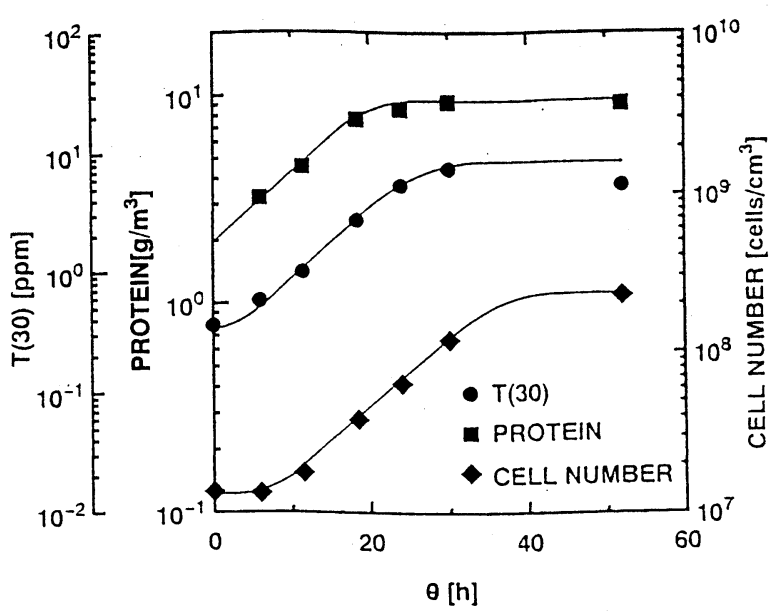

Fig. 4 Changes in $T(30)$, protein concentration and cell number of the culture solutions with the incubation time.

Table 1 Comparison of specific growth rate $(\mu)$ and doubling time $\left(t_{d}\right)$ of $T$. ferrooxidans using different methods.

\begin{tabular}{lcc}
\hline \multicolumn{1}{c}{ method } & $\mu\left[\mathrm{h}^{-1}\right]$ & $t_{d}[\mathrm{~h}]$ \\
\hline Turbidity method & 0.1154 & 6.00 \\
Protein assay & 0.0694 & 9.99 \\
Direct counting & 0.1022 & 6.78 \\
\hline
\end{tabular}

じる濁度は時間とともに低下する。このため, 酸添加後の濁度を 菌体量の指標として用いる際には, 酸添加後の経過時間に十分留 意する必要がある。以下では, 鉄沈殿の溶解に必要な時間を勘案 して, 酸添加後 $30 \mathrm{~min}$ の濁度測定值 $T(30)$ を増殖挙動を把握す るための指標として用いた。

Fig. 4 に, T. ferrooxidans を $9 \mathrm{~K}$ 培地中で培養した場合の濁 度 $T(30)$, タンパク質量, 菌体数と培養時間との関係を一例とし て示す。一般に微生物を回分培養した場合, 増殖曲線は, 誘導期, 対数増殖期, 静止期の順に区分けできる。 $T(30)$ の值は誘導期な しに培養開始直後から指数的に増大し (対数増殖期), $24 \mathrm{~h}$ 以降 ほぼ一定の值となった (静止期)。タンパク質量は, 指数的に増 加した後, $20 \mathrm{~h}$ 以降ほぼ一定の值となった。菌体数は, 培養開 始直後には増加せず（誘導期）, $6 \mathrm{~h}$ 以降, 指数的に増加した。 菌体数で表される増殖曲線で対数増殖期から静止期へと移行する

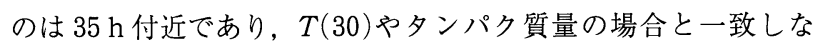
い。このように, $T(30)$, タンパク質量, 菌体数で表される増殖 曲線では, それぞれ誘導期の有無や対数増殖期から静止期に移行 する時期に違いが見られる。菌の増殖過程では, 分裂に先立って 菌体の組成や大きさが変化する。濁度やタンパク質量の測定值は, 菌体の数に加えて, 個々の菌体の大きさや組成などにも依存する。 これに対して, 直接計数法による測定值は, 菌体の大きさや組成 には関係しない。このような測定原理の違いが, 増殖曲線の差と して現れたものと考えられる。Fig. 4 から求めた比增殖速度と世 代交代時間を Table 1 に示す。なお比増殖速度 $(\mu)$ は, 対数増 殖期において次式で定義される。

$\mathrm{d} X / \mathrm{d} \theta=\mu X$

ここで, $X$ はタンパク質量, 菌体数および濁度であり, $\theta$ は培 養時間である。世代交代時間 $\left(t_{d}\right)$ は, $\mu$ を用いて次式から算 出した。

$$
t_{d}=(\ln 2) / \mu
$$

酸添加濁度法と直接計数法を用いて求めた比増殖速度, 世代交代 
時間は, ほほ一致した。T. ferrooxidans の菌体量測定には, 直 接計数法, タンパク質量測定法が従来多用されているが, 前者は 熟練を要し個人差も大きく, 後者は測定操作が煩雑で多量の培養 液を必要とする。一方, 本研究で提案した酸添加濁度法は, 少量 のサンプルで個人差なく測定でき, 直接計数法, タンパク質量測 定法と比較してより簡便であり，有用な方法の一つと考えられる。

4.2T. ferrooxidans の增殖および鉄（II )イオン酸化活 性に及ぼすポリオキシエチレン化合物の影響

界面活性剂 Tween20 は, 適切な添加濃度の下で黄銅鉱のバク テリアリーチングを促進する（Duncan ら，1964；広吉ら，1994， 1995)。また, Brij35, PEG200, PEG2000, PEG20000は, 適切 な条件下で, 硫酸鉄 $($ III )による黄銅鉱の浸出を促進し，バクテリ アリーチングの浸出促進剤としての使用が期待できる。 (Sandval ら, 1991; 広吉ら, 1994)。ここでは, 酸添加濁度法 を用いて，これらの試薬が T. ferrooxidans の増殖速度，鉄 (II) イオン酸化活性に及ぼす影響について調べた。実験結果の一例と して, 9K 培地に Tween20 を種々の濃度で添加して培養したと きの $T(30)$ 抢よび鉄 (III) イオン濃度の経時変化を, Fig. 5， 6 に それぞれ示す。添加濃度が 0,10 および $100 \mathrm{~g} / \mathrm{m}^{3}$ の場合, $T(30)$ の値は培養開始後しばらくすると指数関数的に増大し, 一定值に 達した。最終的に到達する $T(30)$ の值は添加濃度に依らないが, 増殖速度は添加濃度の増大に伴いわずかに小さくなった。添加濃 度 $1,000 \mathrm{~g} / \mathrm{m}^{3}$ の場合, $T(30)$ の值は増加せず, 増殖は認められ

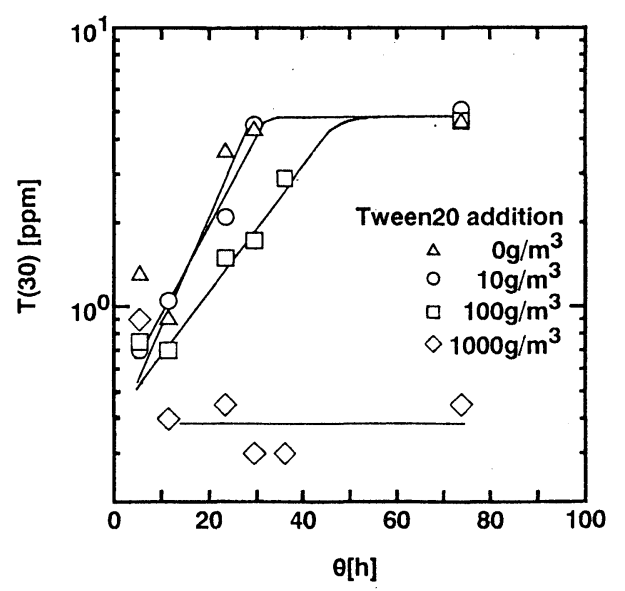

Fig. 5 The effects of Tween 20 addition on the cell growth of $T$. ferrooxidans.

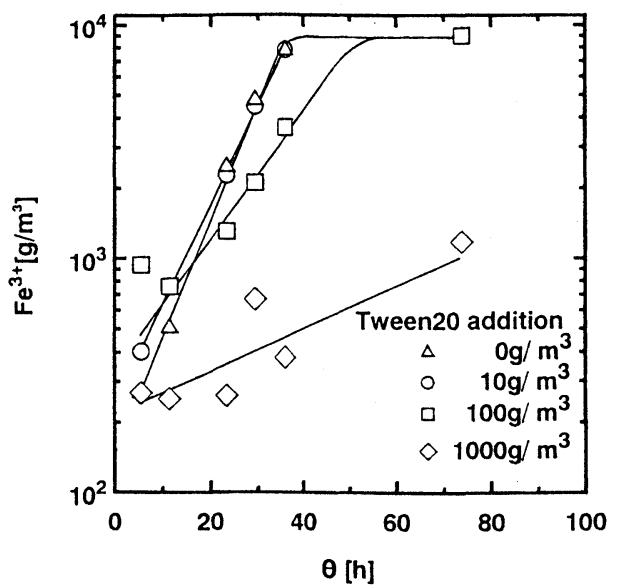

Fig. 6 The effects of Tween 20 addition on the ferrous oxidation ability of $T$. ferrooxidans.
なかった。なお，直接計数法による菌体数の測定結果からも，添 加濃度の増大に伴う増殖速度の低下が確認できた。Fig. 6 中の 鉄 ( III) イオン濃度は, 初期鉄 (II)イオン濃度から各測定時間にお ける鉄 ( II )イオン濃度を差し引いて算出したものである。鉄 ( III ) イオン濃度は, いずれの添加濃度の場合も指数関数的に増大した が, その勾配は添加濃度の増大に伴い小さくなった。以下では, この勾配を鉄 ( II ) イオン酸化速度 $k$ とする。

Fig. 7 は, 增殖速度に及ぽす各種ポリオキシエチレン化合物 の添加濃度の影響を示したものである。同図の縦軸には，ポリオ キシエチレン化合物を添加したときの比増殖速度 $\mu$ を, 無添加 のときの比増殖速度 $\mu_{0}$ で除した值を示してある。Tween20, P EG2000, PEG20000 を添加した場合, 添加濃度の増大に伴い増 殖速度は低下し, $1,000 \mathrm{~g} / \mathrm{m}^{3}$ で増殖が認められなくなった。 Brij35 は $10 \mathrm{~g} / \mathrm{m}^{3}$ で増殖を抑制し, $100 \mathrm{~g} / \mathrm{m}^{3}$ 以上添加した場合 には，増殖が認められなかった。PEG200は， $100 \mathrm{~g} / \mathrm{m}^{3}$ 以下で は増殖にほとんど影響を及ぼさないが, $1,000 \mathrm{~g} / \mathrm{m}^{3}$ では増殖を 抑制した。

Fig. 8 に, T. ferrooxidans の鉄 (II)イオン酸化活性に及ぼす 各種ポリオキシエチレン化合物の添加濃度の影響を示す。同図の 縦軸には, ポリオキシエチレン化合物を添加したときの鉄酸化速 度 $k$ を無添加のときの鉄酸化速度 $k_{0}$ で除した值を示してある。 Tween20，Brij35 は，添加濃度の増大に伴い鉄 ( II )イオンの酸 化を抑制し，それぞれ $1,000 \mathrm{~g} / \mathrm{m}^{3}, 100 \mathrm{~g} / \mathrm{m}^{3}$ で鉄( II )イオン酸 化を顕著に抑制した。PEG200，PEG2000，PEG20000は，100 g $/ \mathrm{m}^{3}$ 以下の添加濃度では鉄 ( II ) イオン酸化をほとんど妨げない が, $1,000 \mathrm{~g} / \mathrm{m}^{3}$ では鉄（II）イオンの酸化を強く抑制した。

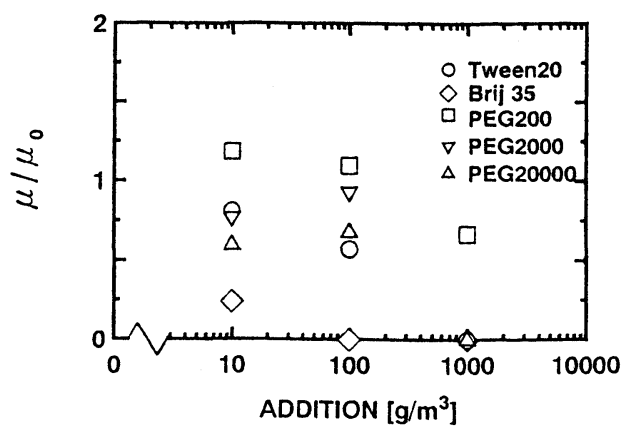

Fig. 7 The effects of polyoxyethylenes addition on the specific growth rate of $T$. ferrooxidans.

The $\mu$ and $\mu_{0}$ are the specific growth rates with and without polyoxyethylens, respectively.

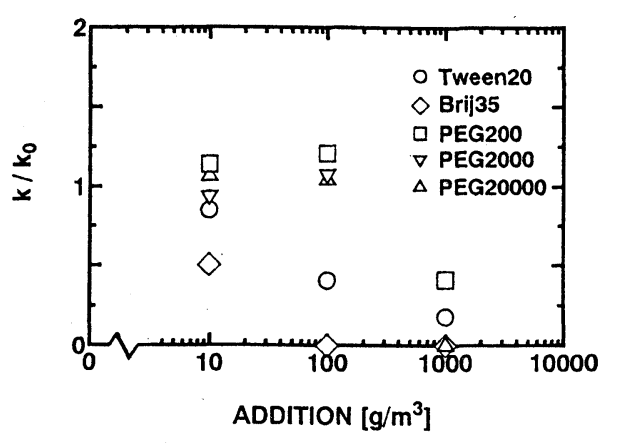

Fig. 8 The effects of polyoxyethylens addition on the ferrous ion oxidation rate.

The $k$ and $k_{0}$ are the ferrous ion oxidation rates with and without polyoxyethylens, respectively. 
Table 2 Volumetric coefficient of mass transfer of oxygen $(A)$ in the presence and absence of polyoxyethylenes.

\begin{tabular}{cc}
\hline polyoxyethylenes $\left(1,000 \mathrm{~g} / \mathrm{m}^{3}\right)$ & $A\left[\mathrm{~h}^{-1}\right]$ \\
\hline No addition & 4.96 \\
Tween 20 & 5.41 \\
Brij 35 & 6.64 \\
PEG 200 & 6.19 \\
PEG 2000 & 5.74 \\
PEG 20000 & 5.27 \\
\hline
\end{tabular}

培地中に界面活性剂等を添加すると, 気相から液相への酸素の 移動速度が低下して微生物による基質酸化, 増殖が抑制されるこ とがある（山根, 1989)。しかし, Table 2 に示すように, 本研 究で使用したポリオキシエチレン化合物はいずれも酸素移動係数 をわずかに増大させており, 気液界面での酸素移動が鉄（II）イオ ン酸化を律速するとは考えられない。高濃度のポリオキシエチレ ン化合物が T. ferrooxidans の增殖と鉄( II ) イオン酸化活性を抑 制するのは, これらの化合物が細胞周縁部一吸着し, 細胞膜内酵 素系や基質の細胞膜透過などに影響を与えることによるものと推 察される。

\section{5. 結}

鉄（II）イオンを基質とした T. ferrooxidans の培養過程では， 鉄沈殿が生成してくるため, 菌体量測定に濁度法を用いることが できず, 従来, 直接計数法や夕ンパク質量測定法を用いてきた。 本報では，より簡便に増殖挙動を把握するため, 培養液中の鉄沈 殿を酸により溶解した後に濁度を測定する方法（酸添加濁度法）
を考案し，基礎的な事項について検討した。

T. ferrooxidans を $9 \mathrm{~K}$ 培地で培養し, 所定時間ごとに採取した 培養液 $3 \mathrm{ml}$ に同容の $6 \mathrm{~N}$ 塩酸を添加すると, $30 \mathrm{~min}$ 以内に培養 液中の鉄沈殿は溶解した。酸添加 $30 \mathrm{~min}$ 後の濁度 $T(30)$ は, 培 養時間の経過に伴い指数関数的に増大した後, やがて一定值とな り, 増殖曲線に対数増殖期, 静止期が明瞭に認められた。酸添加 濁度法と直接計数法, タンパク質量測定法とを比較し, 各測定法 の特徵を明らかにした。酸添加濁度法を用いて, Tween20, Brij 35 ，および分子量の異なる 3 種のポリエチレングリコールをそれ ぞれ含む $9 \mathrm{~K}$ 培地中で, T. ferrooxidans の増殖挙動, 鉄 ( II ) イオ ン酸化活性を調べたところ, いずれの試薬も $1,000 \mathrm{~g} / \mathrm{m}^{3}$ でその 増殖と鉄 $($ II )イオン酸化を著しく抑制した。

謝辞本研究の一部は, 文部省科学研究費補助金（試験研究 (B) (2)－05555274）により行われた。ここに記して謝意を表す。

\section{引用 文 献}

Duncan, D. W., Trussell, P. C. and Walden, C. C. (1964) : Applied Microbiology, Vol. 12, p. $122-126$

広吉直樹 - 恒川昌美 - 平島 剛 - 高森隆勝 (1992) : 資源と素材, Vol. 108, p. 129133

広吉直樹 · 中村 剛 - 恒川昌美·平島 剛 (1994)：資源・素材学会 1994 年度春季大 会講演要旨集, p. $137-138$

広吉直樹 - 中村 剛 - 恒川昌美 - 平島 剛 - 伊藤真由美 (1995), : 資源と素材, Vol. 111 , p. $943-948$

日本生物工学会編（1992）: 生物工学実験書, 培風館, p. 27-28

Sandoval, S. P., Pool. D. L. and Scholtze, L. E. (1991) : Rep. Invest. US Dep. Inter. Bur. Mine, No. 9381 , p. 14

Silverman, M.P. (1967) : J. Bacteriol., Vol. 94, p. 1046-1051

山根恒夫（1989）：生物反応工学, 産業図書株式会社, p. 197 